\title{
Status of Automobile Industry Post Covid-19
}

\author{
Dr. Anita Satish Sathe, Associate Professor, Haribhai V. Desai College, Pune, Maharashtra, India. \\ anita_sathe_2006@yahoo.co.in
}

Abstract - In December 2019 there was an outbreak of corona virus emerging from Wuhan, China and it slowly spread all over the world. As the virus being highly contagious causing respiratory infections ultimately leading to some fetal cases, it was necessary to respond to this unprecedented crisis of the disease COVID-19 by taking drastic measures. Hon. Narenra Modi ,Prime Minister of India announced 'Janata Lock- Down' for the first day followed by compulsory lock down in the entire nation initially for three weeks which later on was extended in order to prevent contamination of the virus amongst Indian nationals to retard the speed of contamination .

This paper highlights the effects on the Automobile Industry during the times of lockdown. It throws light on issues like position of automobile industry in India, impact of lockdown on Auto Industry due to COVID-19, fiscal measures suggested in order to boost Auto industry and also challenges before the industry etc. during the recovery after the lockdown period. The paper is based on secondary data.

Key words: lock down, auto industry, position, fiscal measures, new challenges

About THE AUTOMOBILE INDUSTRY In INDIA

The automotive industry is a term that covers a wide range of companies and organisations, which are involved in the design, development, manufacture, marketing, and selling of motor vehicles, towed vehicles, motorcycles and mopeds. It is one of the world's most key economic sectors by revenue. In India this sector currently contributes to fifty percent of the manufacturing gross domestic product (GDP).It accounts to twenty -six percent of the Industry GDP and 7.1percent of overall GDP. This sector contributes to $13 \%$ approximately of excise revenue to government.

The Indian automobile industry is the fourth largest in the world. The industry includes two-wheeler, four-wheeler, passenger vehicle and commercial vehicles. It has an annual turnover of $\$ 100$ billion and employs 32 million people. India has largest two-wheeler industry in the world. This segment dominates the industry with a share of 80 per cent. India is also the largest manufacturer of tractors in terms of unit numbers.

During the last decade, total investment in this sector is around $\$ 40$ billion. The decade of 2001-2010 saw a compounded annual sales growth of 15.67 per cent, out of which 10 per cent were exports. Due to constant government support, the yearly growth of exports was 23 per cent from 2000 to 2015. In 2018-19, 4.06 million cars were manufactured and at present around 32 million cars run on Indian streets. However from 2019-20 this sector was facing trouble in maintaining sales and profitability. Due to subdued market confidence, slow economic operations and crisis in non banking financial companies, domestic sales of Maruti Suzuki - the market leader dropped by $35.9 \%$.

\section{About COVID-19}

COVID-19 Pandemic- From December 2019 there was outbreak of corona virus due to which the global economy is severely affected. Corona viruses are a large family of viruses. They may cause illness in animals or humans. In humans, several corona viruses are known to cause respiratory infections ranging from the common cold to more severe diseases such as Middle East Respiratory Syndrome (MERS) and Severe Acute Respiratory Syndrome (SARS). The most recently discovered corona virus causes corona virus disease known as COVID-19.

COVID-19 is the infectious new virus and disease. It is hyper contagious in nature. It is caused by corona virus which is most recently discovered. Till its outbreak began in Wuhan, China, in December 2019, the virus and disease were unknown. COVID-19 is now a pandemic affecting many countries globally. The disease spreads primarily from person to person through small droplets from the nose or mouth, which are expelled when a person with COVID19 coughs, sneezes, or speaks. The outbreak of corona virus disease 2019 (COVID-19) has created a global health crisis that has had a deep impact on our everyday lives, business and industry and the economy. The risk of an outbreak in India is particularly high due to the high density population of India's cities and towns-465 people per square kilometer compared to China's 145.

On 25 March, one day after a complete 21-day lockdown was announced by the Prime Minister. The Hon'ble Prime Minister of India has made absolutely the right decision to place the entire country under lockdown 
for three weeks in order to control the spread of the corona virus and ensure the safety and well being of everyone. On 14 April 2020, the Prime Minister of India extended the lockdown to 3 May and then again it was extended till $17^{\text {th }}$ May due to unsatisfactory results in recovery over number of patients suffering from the pandemic.

\section{IMPACT OF COVID-19}

In India this pandemic has been hugely disruptive. India's growth for fiscal year has shown lowest figures during the last three decades. During the lockdown, an estimated 140 million (140 million) people lost employment. More than $45 \%$ of households across the nation have reported an income drop as compared to the previous year. Like the other sectors in economy, automotive industry is also facing hard times on account of factory shutdown, dealer's lockdown, supply chain disruption etc.

The March 2020 numbers show the effect of lockdown due to the COVID-19 pandemic. The last month of any financial year is usually the peak period for inventory clearance for the industry. The position of some of the automobile companies was as follows:

\section{Status of Various Automobile Manufacturing Companies}

- For Maruti Suzuki sales for domestic passenger vehicle fell from 145000units in March 2019 to 76240 units in March 2020. Export sales came down almost to 55\% i.e. from 10463 units a year ago to 4712 units. Overall sales reduced by $16 \%$ i.e. from 1.862 million in the previous fiscal to 1.563 million units during financial year end March2020

- For Hyundai Motor India, there was decline in sales to 26300 units in March 2020.

- Similar trend was seen in Mahindra and Mahindra's domestic passenger vehicles which reduced from 27,637 units in March 2019 to 3384 units in March 2020 .

- Bharat Stage 6 (BS6) emission norms were to be implemented from Bharat Stage 4 (BS4) from April 1, 2020 , which has also added to the woes of this sector. This brought in long-term problems from both endsmanufacturing to sales point. i.e. such as research and development, technological up-gradation and closing down of plants to stop piling up of old inventory etc. The demand s of BS4 vehicles dropped, due to which inventory of old (BS4) vehicles both in two-wheeler and four-wheeler segments increased. On $27^{\text {th }}$ March2020 Federation of Automobile Dealers Associations appealed to the Supreme Court to allow the sale of BS4 vehicle inventory which has piled up amid the COVID-19 crisis. But only $10 \%$ of inventory could be sold out. The unsold stock accounted to around 700,000 two-wheelers worth Rs 3850 crores,
15,000 passenger cars worth Rs 1050 crores and 12,000 commercial vehicles i.e. slow moving trucks and buses worth Rs 1440 crores. Auto dealers- 15000 odd-dealer community were stuck with Rs 6000crorer inventory. The second half of March is typically a busy time for any automobile dealership in the country. Targets have to be met at the end of the fiscal year. It is also a time when corporate sales should be at the highest so that companies can avail depreciation benefit for vehicles bought for official purposes. Estimated figures given by Federation of Automobile Dealers Association indicate that 26,000 dealerships in the country were to be left with BS IV stocks worth Rs 6340 crore. As all dealers in the country would remain closed till April 14, this pile up of inventory would be reduced to junk on the morning of April 1.

In July 2019, leading Non Banking Financial CompaniesInfrastructure Leasing \& Financial Services (IL\&FS) and Dewan Housing Finance Ltd (DHFL) -financed almost 70 per cent of new two-wheelers and 60 per cent of new commercial vehicles which were sold in the country. When IL\&FS and DHFL went into financial distress, they transmitted this contagion from the financial services sector to automobile sector and dragged it down. This also led to closure of few dealerships.

\section{AUTOMOBILE INDUSTRY IN LOCKDOWN}

After the government declared a nationwide lockdown on March 24, 2020 to prevent spread contamination of the virus; the reverse gear of the Indian auto industry came immediately as to support the lockdown, all automakers like Maruti Suzuki, Honda, Hyundai, Tata Motors, Mahindra and Mahindra, Toyota Kirloskar Motors, Kia Motors and others immediately temporarily closed down their plants . Also the two-wheeler manufacturers like Hero MotoCorp, Honda Motorcycle, Scooter India, TVS Motor Company, Bajaj Auto, Suzuki Motorcycle and Yamaha closed down manufacturing activity. Operations of many leading automobile plants were closed for few days to halt production. This resulted in loss of jobs of the contractual workforce. Macroeconomic issues also cropped up that added to this crisis i.e. there was the decline in demand/consumption both from the rural and urban markets and also a liquidity crunch in the financial markets. NBFCs have had an enormous exposure to vehicle financing in the country, covering all segments.

According to Society of Indian Automobile Manufacturers the plant closure of auto original equipment manufacturers and component manufacturers would lead to a loss of Rs 2,300 crore per day and loss of revenue of Rs 48,300 crore due to a cumulatively three-week shut down of the automotive industry .

The government on $2^{\text {nd }}$ May 2020 extended the period of lockdown by another two weeks till May 17 but has 
provided a number of caveats to ensure resumption of economic activity in the country. The automotive industry however wants the entire value chain, which includes suppliers, manufacturers, dealers across the country to be allowed to open in one go for the efficient functioning of the industry.

\section{Effect on Share Prices}

- Motherson Sumi Systems and Hero Moto Corp were down 2 per cent each,

- Bajaj Auto, Cummins India, TVS Motor Company were trading lower 1 per cent each on the Bombay Stock Exchange

- The BSE Auto index, which opened 2.5 per cent higher at 16,123.70, but declined in index for companies like Hero MotoCorp, Bajaj Auto and TVS Motor Company. In the volatile trading session, the BSE Auto index declined as much as 0.2 percent to touch an intra-day low of $15,472.05$ against previous close level of $15,728.03$.

- However, Ashok Leyland was up by 5.15 percent, Bosch was up by 3.45 percent, Mahindra \& Mahindra was up 1.39 percent, and Eicher Motors was up by 0.57 percent

\section{Fiscal Measures}

In middle of a prolonged slowdown, the automobile industry has requested the government to take bold fiscal measures to revive the automobile sector .In the upcoming Union Budget, the auto industry has sought measures, such as

1) Reduction in GST rates on vehicles - In order to revive demand, the sector has requested government to reduce GST on BS VI vehicles from 28 percent to 18 percent. This was because the introduction of BS VI vehicles, would lead to increase in cost by $8-10 \%$ which would enhance GST collection for government. This extra cost could lead to fall in demand. Therefore the demand is to be boosted.

2) Abolition of duty on import of lithium-ion battery cells, to encourage electric mobility.

3) Incentive based scrap page policy is announced and there will also be increase in re-registration charges of vehicles to discourage use of old vehicles. They have asked to withdraw hike in registration fee permanently.

4) The industry has also sought adequate Budget allocation for the Ministry of Urban Development to support state transport undertakings in procuring buses. Robust public transportation will reduce the number of vehicles on the road which will reduce pollution which will have positively impact climate change. This would also help to reviving demand for commercial vehicles which is very much needed in the current economic scenario.

6) The industry has asked increase in depreciation rate on passenger vehicle and two-wheelers to $25 \%$ to have depreciation aligned to real useful life of the vehicle.

7) The sector demands income tax benefits on the interest part of vehicle loan to be provided to individuals who purchase green vehicles.

\section{Challenges for the automobile industry}

Challenges in Research and Development

1) Delayed launches i.e. delay in product development activities which will be adding time to market

2) Uncertain future of Rand D programmes-due to uphold in launches and restricted cash position and also ambiguity of continuation of government policies in stage of economic crisis, there will be lack of clarity on future projects

3) The scenario also calls for addition new features of disinfection -which will need more recourses and funds and innovative thought process.

\section{Challenges in Procurement}

1) Material shortage due to financial and labour distress at domestic suppliers

2) Disrupted supply chains with special reference to global suppliers in COVID-19 regions

3) Delay in custom and port clearance due to mandatory shipment quarantine

\section{Challenges in Manufacturing}

1) Loss of productivity - due to nationwide lockdown, subdued demand and 'safe distancing on shop floors'

2) Shortage of labour - due to migration of workers and low degree of automation especially for Suppliers

\section{Challenges in Finance}

1) Higher cost of input- as cost of imported raw material will increase due to rupee devaluation and high volatility in prices of few items because of pandemic induced demand

2) Cash management will be difficult- higher working capital will be needed due to delayed payments and cash crunch.

\section{SUMMERY}

With the entire industry reporting zero sales in April, the domestic automobile sector has written to the government seeking relaxation from the lockdown to ensure full resumption of operations to the entire value chain. Some top manufacturers such as Maruti Suzuki India Ltd, Hero MotoCorp Ltd, Honda Motorcycle \& Scooter India Pvt. 
Ltd ,Hyundai Motor India Ltd, , and Bajaj Auto Ltd have begun to monitor the readiness of their vendors for resuming supplies. Renault Nissan- Chennai-based, has informed its suppliers that it plans to resume vehicle and powertrain production from June 2020. Yamaha officials opined that the original equipment manufacturers (OEMs) will take some time after the lockdown to start their operations. Puneet Gupta, associate director at market research firm IHS Markit, said that it would be a big challenge to roll out vehicles from those companies who have a marginal share of the Indian car market. He added that it becomes difficult to keep dealers, suppliers and other agencies engaged for small volumes. To minimize the losses, a smart strategy for small players would be to start only when they see demand in the market. Auto industry is looking for the entire value chain, which includes factories of all component makers, vehicle and two-wheeler manufacturers, as well as dealerships, across the country to be allowed to open in one go.

Even when the lockdown is officially lifted, consumers' buying behavior is expected to have been changed. The NRI study suggests that understanding these changes in consumers' needs will play a key role in the auto industry's recovery in the post COVID-19 phase.

\section{REFERENCES - GOOGLE SEARCH}

[1] Commercial aspects of COVID-19 Webinar ETAuto Townheal: Indian Auto Industry to get back to normal...Vikram Kirloskar

[2] Webinar-ETAuto Virtual Roundtable, impact of COVID-19 on EV business

[3] Automobile Industry in lockdown

[4] Auto Industry in India

[5] Business Today

[6] Business Today- business today in 21 days lockdown

[7] Hero Motor Corp, Bajaj Auto

[8] Business Today-Budget2020

[9] www.entrepreneur.com

[10] Information about COVID- World Health Organisation

[11] https://www.frontiersin.org/

[12] https://en.wikipedia.org/

[13] https://Livemint.com

[14] http://financialexpress.com 